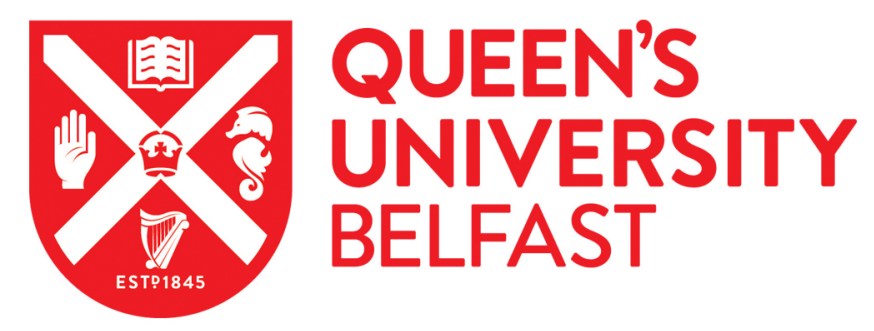

\title{
Vetting Sexual Offenders: State Over-extension, the Punishment Deficit and the Failure to Manage Risk
}

McAlinden, A-M. (2010). Vetting Sexual Offenders: State Over-extension, the Punishment Deficit and the Failure to Manage Risk. Social and Legal Studies, 19(1), 25-48. https://doi.org/10.1177/0964663909346197

Published in:

Social and Legal Studies

Document Version:

Early version, also known as pre-print

Queen's University Belfast - Research Portal:

Link to publication record in Queen's University Belfast Research Portal

\footnotetext{
General rights

Copyright for the publications made accessible via the Queen's University Belfast Research Portal is retained by the author(s) and / or other copyright owners and it is a condition of accessing these publications that users recognise and abide by the legal requirements associated with these rights.
}

Take down policy

The Research Portal is Queen's institutional repository that provides access to Queen's research output. Every effort has been made to ensure that content in the Research Portal does not infringe any person's rights, or applicable UK laws. If you discover content in the Research Portal that you believe breaches copyright or violates any law, please contact openaccess@qub.ac.uk. 


\title{
Social \& Legal Studies
}

http://sls.sagepub.com

\section{Vetting Sexual Offenders: State Over-Extension, the Punishment Deficit and the Failure to Manage Risk \\ Anne-Marie McAlinden \\ Social Legal Studies 2010; 19; 25 \\ DOI: $10.1177 / 0964663909346197$}

The online version of this article can be found at: http://sls.sagepub.com/cgi/content/abstract/19/1/25

\author{
Published by: \\ (SAGE \\ http://www.sagepublications.com
}

Additional services and information for Social \& Legal Studies can be found at:

Email Alerts: http://sls.sagepub.com/cgi/alerts

Subscriptions: http://sls.sagepub.com/subscriptions

Reprints: http://www.sagepub.com/journalsReprints.nav

Permissions: http://www.sagepub.co.uk/journalsPermissions.nav

Citations http://sls.sagepub.com/cgi/content/refs/19/1/25 


\title{
VETTING SEXUAL OFFENDERS: STATE OVER-EXTENSION, THE PUNISHMENT DEFICIT AND THE FAILURE TO MANAGE RISK
}

\author{
ANNE-MARIE MCALINDEN \\ Queen's University Belfast, UK
}

\begin{abstract}
This article examines the state regulation of sexual offenders in the particular context of pre-employment vetting. A successive range of statutory frameworks have been put in place, culminating in the Safeguarding Vulnerable Groups Act 2006, to prevent unsuitable individuals from working with the vulnerable, and children in particular. Contemporary legislative and policy developments are set against a backdrop of broader concerns in the area of crime and justice, namely risk regulation, preventative governance and 'precautionary logic'. Proponents of these approaches have largely ignored concerns over their feasibility. This article specifically addresses this fissure within the specific field of vetting. It is argued that 'hyper innovation' and state overextension in this area are particularly problematic and have resulted in exceptionally uncertain and unsafe policies. These difficulties relate principally to unrealistic public expectations about the state's ability to control crime; unintended and ambiguous policy effects; and ultimately the failure of the state to deliver on its self-imposed regulatory mandate to effectively manage risk.
\end{abstract}

\author{
KEY WORDS \\ precautionary logic; risk; regulation; sex offenders; vetting
}

\section{$\underline{\text { INTRODUCTION }}$}

$\mathrm{P}$ OST-MODERN debates on security and justice have been classified by a marked emphasis on 'regulation' and 'governance'. The new era of the 'regulatory state' (Majone, 1994; Braithwaite, 2000; Moran, 2001), or the

Social \& LEgAl STUDies (C) The Author(s), 2010

Reprints and Permissions: http://www.sagepub.co.uk/journalsPermissions.nav

0964 6639, Vol. 19(1), 25-48

DOI: $10.1177 / 0964663909346197$ 
'post-regulatory state' (Black, 2001; Scott, 2004), as others prefer, has seen the global emergence of a risk-based logic which has re-shaped the use of punishment as a regulatory mechanism (Beck, 1992; Ericson and Haggerty, 1997; Shearing, 2000). Scholars have highlighted contemporaneous developments in the governance of anti-social behaviour and community safety within civil society (Crawford, 1997, 2003), as well as policing or security in general (Shearing, 2000; Loader and Walker, 2007), as useful illustrations of the minutiae of state control of crime and disorder. This article will consider the implications of these debates for the regulation of sex offenders in the United Kingdom, particularly within the context of pre-employment vetting.

A distinguishing feature of contemporary trends in social regulation is what has been termed 'hyper innovation' (Moran, 2003; Crawford, 2006) which takes place against a backdrop of the overt politicization of deviant behaviour. Over the last decade there has been unprecedented law and policy making in the area of behavioural and social control. The 1997 Labour government, under the banner of 'New Labour', was elected on a strong 'law and order' ticket reflecting Prime Minister Blair's mantra, 'tough on crime, tough on the causes of crime' (Tonry, 2003). Between 1997 and 2005, over 1000 new criminal offences were created within 43 crime-related pieces of legislation (Crawford, 2006: 457). These figures are indicative of what Lacey (2004) calls 'criminalisation as regulation', where the state attempts to assert its authority via the imposition of a burgeoning amount of criminal sanctions.

There has been an increasing emphasis on notions of 'risk' and 'regulation' for a minority of criminals for whom exceptional forms of punishment and control are thought necessary (Zedner, 2009). Such authoritarianism has resulted in the marginalization and criminalization of targeted deviant groups (Scraton, 2004), including sex offenders. The state's prioritization of the dangers posed by potential sex offenders over other forms of deviant behaviour is driven in large part by media-fuelled popular discourses concerning risk. Sex offenders are singled out for special consideration because of the emotive nature of the crime, particularly where children and the vulnerable are concerned. Consistent with the broader concerns of criminologists that expansive forms of state regulation are leading to increasingly volatile, contradictory and incoherent penal policies (Garland, 1999; O’Malley, 1999; Crawford, 2001), this article will argue, however, that regulatory activity in the fields of child protection and sex offender management has resulted in particularly uncertain, insecure and unsafe policies (Bauman, 1999), predominantly in relation to vetting.

A related area of debate concerns the emergence of a policy of 'radical prevention' (Hebenton and Seddon, 2009: 2) in relation to sex offending. Scholars have charted the development of the theoretical underpinnings of criminal justice policy which has shifted 'From Dangerousness to Risk' (Castel, 1991) towards a defining contemporary framework based on 'precautionary logic' (Ericson, 2007). This pre-emptive approach to penal policy is characterized by the quest for security and certainty via the imposition of reactionary risk-averse policies which seek to govern 'worst case scenarios' 
and prevent all possible manifestations of future risk before they occur (Zedner, 2009). Others have noted the significance of the precautionary principle in the global response to terrorism post-9-11 (Ignatieff, 2004; Zedner, 2005) and in the American and British response to protecting the public from known dangerous violent and sexual offenders via, for example, exclusionary measures such as sex offender registration and community notification and preventive detention (Seddon, 2008; Hebenton and Seddon, 2009). This article seeks to analyse and refine the implications of these associated debates within the specific context of pre-employment vetting which attempts to preemptively respond to both known and unknown risks posed by sex offenders.

In recent times we have witnessed 'the institutionalisation of vetting' (Furedi and Bristow, 2008: xii) which has further entrenched the rhetoric of precaution through a chain of legislative and policy proposals, culminating most recently in the Safeguarding Vulnerable Groups Act 2006. It will be argued, however, that recent measures which attempt to regulate all those who would work with children or the vulnerable to minimize potential risks have been implemented and are likely to be played out under conditions of extreme uncertainty. Pre-emptive measures are premised at best on the claim that it is possible to largely pre-determine who poses a risk and to what extent (Zedner, 2009: 35), and at worst, that any levels of uncertainty are justified by vague claims to potential harms which must be guarded against 'at all costs'. This two-fold justification, however, is not sustainable when it comes to pre-employment vetting and the new legislative framework in particular where the reality of potential harm is clouded by a perceived and misrepresented 'risk'. In the main, there are obvious, yet on the whole unacknowledged, limitations of official knowledge about the risks posed by largely unknown individuals who may have never come to the attention of the authorities for sexually deviant behaviour. Moreover, the resulting ambiguities concerning levels and types of risk operate at the expense of effective risk management and to the detriment of relationships between individuals within civil society.

In effect, in the desire 'to govern risky conditions' or behaviours rather than 'categorically risky types of person', as O’Malley puts it (2004: 318-19), 'social control must be "front loaded"' (Reichman, 1986: 155). Selective, scientific, objective risk assessments, as the hallmarks of 'actuarial justice' (Feely and Simon, 1994), are superseded by subjective, sweeping, speculative assumptions about risk. This has in turn fostered generalized forms of intrusive risk regulation as a precaution where knowledge about actual risks and targeted intervention are replaced by uncertainty (Zedner, 2009: 37). These take the form of inflating embedded levels of societal suspicion, mistrust and intolerance concerning potential sex offenders, (Furedi and Bristow, 2008), and resulting indiscriminate strategies which 'cast the net of suspicion on all' (Ericson, 2007: 259).

As both Crawford (2006: 471) and Zedner (2009: 56) note, concerns about the feasibility of 'responsive regulation' and the 'precautionary principle' respectively have to a large extent been ignored by advocates of these 
approaches. This analysis seeks to remedy this important lacuna by making explicit the dangers and uncertainties inherent in the state assumption of precautionary logic within this specific area of criminal law. The corollaries of state over-extension relate chiefly to unrealistically raising public expectations about the capacity of the state to control risk via punitive regulatory frameworks, unintended or ambiguous consequences of far-reaching legislative and policy frameworks, and uneven implementation (Crawford, 2006). Ultimately, however, in governing under conditions of extreme uncertainty and in the precautionary approach that this prompts, there is a failure to address the underlying policy and practical issues and actively manage risk.

The structure of the article will be as follows. In order to fully understand the new legislative framework, the article first places the 2006 Act in its contemporary context. Part I critically examines the social, cultural and political context in which vetting has developed and the intrinsic politics of popular and official discourses. Part II outlines some of the key features of the new legislative framework with a view to highlighting its underlying rationale, the previous deficiencies in the law which it was designed to address, and the potentially expansive scope of the new vetting and barring scheme. Finally, Parts III and IV will draw out some of the principal dangers and uncertainties resulting from state over-extension in this area of law and policy making. These are grouped chiefly in terms of: (1) 'the punishment deficit'; (2) unintended effects and uneven policy implementation; and (3) ultimately the failure to manage risk.

\section{Part I: The Socio-Political Context of VetTing - THE LEGISLATIVE AND POLICY PROCESS}

In recent years, the management of dangerous or 'risky' individuals, such as paedophiles and persistent violent offenders, has generated enormous popular and official concern. Consistent with broader academic discourses on state regulation, notions of risk management (Parton et al., 1997; Kemshall and Maguire, 2001) and, more recently, preventative governance (Ashenden, 2002) have become the key criteria for the regulation of child (sexual) abuse and the management of sexual offenders in the community more generally. A specific focus of recent policy and organizational processes has been the compilation of 'knowledge' about sex offenders and their whereabouts in order to control risk and increase security (Ericson and Haggerty, 1997).

During the last 10 years or so, the government has come under increasing pressure to be seen to be actively 'doing something' in the face of glaring media focus and heightened public fears concerning the presence of sex offenders in the community (Simon, 1998). As Zedner notes, 'the mentality of precaution feeds on existing insecurities and gives sway to the exercise of fevered bureaucratic imagination' (2009: 58). New state policies in this area typically follow on from high-profile cases of child abuse and murder. In the recent context, there have been two distinct yet interrelated 'moral panics' 
(Cohen, 1972) about sexual offending which require explicit recognition. One is the scandal of long-term institutional and institutionalized abuse of children in care in both church and state settings. The other is the paedophilia 'stranger danger' phenomenon which occurs on a seemingly random basis. As a result of a populist approach to criminal justice policy-making (Bottoms, 1995; Johnstone, 2000), a zero-tolerance approach to risk has developed and a panoply of legislation pertaining to sexual offending has been enacted within a relatively short period.

A range of measures has been enacted to manage the risk posed by sex offenders in the community, such as sex offender registration or notification, risk of sexual harm orders, sexual offences prevention orders, and the recent offence of 'meeting a child following sexual grooming'. ${ }^{1}$ The specific issue of how to prevent sex offenders from using their employment as a cover to target and sexually abuse children, however, has perhaps become one of the most contentious and politicized in the recent popular and official discourses on sexual offending. Between 1997 and 2006, no fewer than five primary legislative reforms were introduced to strengthen vetting procedures and to criminalize those who abuse their position of trust in order to offend against children.

There are usually two polar responses of the state in recognition of its limitations to control crime: a politics of denial of responsibility for the problem (Cohen, 2001); and a politics of punishment as demonstrable evidence of its strength and commitment (Garland, 1996). In relation to the vetting of sex offenders, although there is some evidence of the former, particularly where loopholes or weaknesses subsequently emerge in current policies, the state's response to the regulation of sex offenders can more clearly be related to the latter. The issue of 'Professional Perpetrators' - sex offenders who use their employment as a vehicle to abuse - has been the subject of a spate of legislation for more than a decade (Sullivan and Beech, 2002). New forms of state intervention are often precipitated by scandals in 'times of crisis' which tend to stimulate a bout of regulatory activity in the longer term (Moran, 2003: 28; Agamben, 2005). Many of the recent measures on vetting were drafted and implemented quickly as an immediate precautionary response to an emerging policy crisis.

\section{PUBLIC INQUIRIES}

From the early 1990s onwards, a series of public inquiry reports and official reviews of cases of 'institutional abuse' highlighted the link between institutions, such as care homes, and the sexual abuse of children in particular (Corby et al., 2001; McAlinden, 2006). ${ }^{2}$ Overall, however, the inquiries have reiterated recommendations to improve pre-employment screening and increase levels of child protection, which have not always been acted upon (Parton, 2004). Several inquiries, for example, have questioned the accuracy of vetting practices and the consistency with which the various agencies use 
the system. The Warner Inquiry (1992) concluded that 10 per cent of the heads of care homes and a third of workers were able to take up their posts without references. Six years later, the Utting Report (1998) also expressed 'serious concerns about the manner in which police checks were handled' and highlighted that insufficient consideration was given to reference procedures. Most recently, the Bichard Inquiry (2004) $)^{3}$ highlighted serious failings in the way in which the police managed their intelligence systems. As Sullivan and Beech (2002) argue, this raises questions not only about the speed and process of institutional change in this area but also, more crucially, whether any lessons have actually been learned.

Indeed, the institutional gaze of many of these inquiries and related public discourses has been too narrow in focus and as such has tended to impede a meaningful and effective review of policy and procedures. ${ }^{4}$ In short, the rather linear focus on accountability and apportioning blame for acts or omissions within the context of a particular crisis or scandal does not permit a fuller consideration of the systemic problems of child care institutions or vetting practices and the wider policy issues concerning sex offender management. In relation to child abuse inquiries in particular, it has been demonstrated that child care institutions are especially self-protective, secretive and closed by nature (Wescott, 1991: 15-17; Sullivan and Beech, 2002: 162). As such, they strongly discourage the drawing of attention to any deficiencies in policies and procedures. ${ }^{5}$

\section{KEY LEGISLATIVE DEVELOPMENTS}

Other recommendations from the official inquiries and reviews eventually resulted in a concentration of piecemeal legislative developments. These measures have generally attempted to improve child care practice and to prevent sex offenders from making contact with children through organizations. For example, Section 3 of the Sexual Offences (Amendment) Act 2000 made it a specific offence for someone to engage in sexual activity with a person under 18 if they are in a position of trust in relation to that person. ${ }^{6}$ Sections 26-38 of the Criminal Justice and Court Services Act 2000 made it an offence for convicted abusers to seek employment with children or for employers to knowingly appoint such people. The majority of the recent measures, however, are based around pre-employment vetting. Part V of the Police Act 1997 established the Criminal Records Bureau, set up in 2002, to co-ordinate criminal record checks. The Protection of Children Act 1999 combined the Consultancy Service Index and 'List 99' to make it easier for employers to check whether applicants who wish to work with children are known or suspected abusers.

Such an ad hoc style of state regulation means that ever-expanding modes of vetting are enacted ostensibly as a 'quick-fix solution' to simply cover up perceived cracks and failures in the regulatory framework as they emerge. This well-established approach to penal policy continues to mask problems 
inherent in the regulatory framework and in the practice of vetting in particular. In the main, there is an apparent state and public over-reliance on vetting in order to increase society's feelings of safety and security. However, it is argued that in such a frenzied approach to law making, state regulation of pre-employment screening in order to expand control and pre-emptively address potential risks may actually end up exacerbating the problem.

\section{Part II: The Safeguarding Vulnerable Groups Act 2006}

The Safeguarding Vulnerable Groups Act 2006 is the most recent in a long line of legislative measures on pre-employment vetting. The new scheme has been operational since October 2009, with transitory provisions in place in the interim. ${ }^{7}$ The Act introduces a new statutory framework and gives legislative effect to many of the recommendations of the Bichard Inquiry (Gillespie, 2007). It recommended, inter alia, the introduction of a national registration system for those deemed suitable to work with children and improved information sharing between agencies (Bichard, 2004: 13-17).

The new vetting and barring scheme resembles a form of state-licensing of those permitted to engage in certain routine activities with children or the vulnerable. The Act is centrally concerned with two broad categories of activity, termed 'regulated activities' and 'controlled activities'. The former covers forms of close contact work with children such as work in schools and care settings and managerial positions where there are key responsibilities. The latter covers ancillary work in education and health settings, such as cleaning or catering, and administrative work involving access to sensitive information about these protected groups. A person who fails to undergo the requisite Criminal Records Bureau checks and get on the register will be guilty of a criminal offence if they work with children or vulnerable adults. It is an offence for a barred person to seek to, offer to, or engage in a regulated activity. Moreover, employers can also be liable for either using a barred person or for failing to vet their employees. It is proposed to outline the key features of the new statutory framework together with the perceived failings of the previous regulatory scheme which they were designed to address.

\section{THE VETTING PROCESS}

Vetting involves a series of different background checks to enable employers to safeguard against employing a barred or restricted person via a two-stage process. Before the adoption of the current statutory framework, the first stage was essentially comprised of a check against three distinct lists of known offenders which were compiled according to different criteria. First, 'List 99' (maintained under section 142 of the Education Act 2002 by the Department of Education and Employment) contained details of people either barred or restricted from working in schools on the grounds not only 
of misconduct but also on medical grounds. For those with convictions for 40 of the most serious offences, inclusion on this list was automatic. For all other cases, including cautions, the decisions were based on ministerial discretion. Secondly, the 'Protection of Vulnerable Adults Scheme' (introduced by Part 7 of the Care Standards Act 2000 and maintained by the Department of Health) covered those banned from working in care homes and domiciliary agencies in England and Wales having previously harmed vulnerable adults in their care. Thirdly, the 'Protection of Children Act List' (introduced under the Protection of Children Act 1999) combined the Department of Health Consultancy Service Index, which set out the names of previous child care workers about whom concerns exist around their suitability to work with children, and 'List 99'. The second stage was disclosure following a criminal records check of police files. ${ }^{8}$

A further supposed layer of 'checks', albeit not strictly conceptualized in pre-employment terms, was the sex offenders register, originally provided for by Part I of the Sex Offenders Act 1997, and subsequently re-enacted by Part 2 of the Sexual Offences Act 2003. 'The register', or notification schemes as they are more properly known, requires certain classes of sex offenders to register their details with the police. Since 2005, this information has been held on ViSOR (the Violent and Sex Offender Register) - a central searchable nationwide database of detailed information on known sexual and violent offenders, linked to the Police National Computer. ${ }^{9}$

\section{PRACTICAL PROBLEMS WITH THE VETTING PROCESS}

Before the reformulation of the current statutory framework there were practical problems with the vetting process in general, and with the operation of the key List 99 in particular. The latter was much wider than just sexual offences and covered those convicted of crimes such as deception offences. Somewhat confusingly, no details of the misconduct were provided (Department of Education and Employment, 1995: para. 52) and given the breadth of its scope, it was of little practical utility since obviously not all those on this list necessarily posed a danger to children. The nature of the discretionary decision led to anomalies and inconsistencies and effectively meant that in some cases an individual was not on List 99, despite being on the sex offenders register. This was mainly attributable to the fact that cautions have historically been treated as different from convictions for vetting purposes, even though they both represent a legal statement of guilt (Gillespie, 2006). ${ }^{10}$

The process of pre-employment vetting as a whole, therefore, was at best confusing and cumbersome as to which 'list' or procedure to follow. There was a lack of coherence in particular between List 99 and the other lists held nationally. Procedures were also characterized by a lack of clarity about individual roles in the vetting process and who bore responsibility for doing what. ${ }^{11}$ At worst, as recent cases demonstrate, these difficulties led to some high-risk individuals slipping through the net. 
Many of these problems were addressed in part by the Safeguarding Vulnerable Groups Act 2006. First, the three separate lists of barred individuals, outlined above, were to be streamlined. The Act establishes a centralized online register and continuous criminal records monitoring of every person who works or volunteers with children or vulnerable adults, to be held in two separate but aligned lists. Second, inclusion on one or both lists would be automatic following a caution or conviction for certain offences but may also be considered when specified behaviour harms a child or vulnerable adult or where evidence suggests risk of harm. Third, an Independent Safeguarding Authority was created, referred to as the Independent Barring Board in the Act, as a statutory body to maintain the lists. This new body will remove previous ministerial decision-making and take all decisions concerning whether an individual is suitable to work with children on a case-by-case basis.

Simplification of the vetting process represents a positive attempt to strengthen and improve pre-employment checks and child protection procedures. Other vestiges of the old regime remain, however, particularly in relation to the uncertainties surrounding the role of individual state agencies and related concerns about information sharing. Operational difficulties are also likely to occur, especially with regard to the significant expansion of vetting into the private sphere. The scope of the new scheme will extend far beyond the traditional education and health care settings to encompass all those who may have contact with children or access to information about them. There are concerns in particular about the nature of system controls on the release of sensitive information about sex offenders and the related consequences of community notification. Indeed, the central argument of this article, as stated at the outset, is that this over-encroachment of the state in the form of ever-expanding precautionary modes of social regulation produces a myriad of uncertainties in the form of raised public expectations, unintended and ambiguous policy consequences and, in due course the undermining of their core aim of effective risk management.

\section{Part III: 'Populist Punitiveness’ and the 'Punishment Deficit'}

As noted above, over the last few years, the state has introduced ever more stringent penal policies in direct response to public fears and insecurities concerning the presence of sex offenders in the community. The state has fuelled 'the politics of culture and fear' (Furedi, 2006a, 2006b) surrounding sex offenders via criminalization and reactive and pre-emptive policing of the potential risks posed by sex offenders. This populist approach to penal policy, however, at once fosters misplaced public perceptions about the risks posed by sex offenders and the ability of the state to curb them.

In January 2006, while the Safeguarding Vulnerable Groups Act was still being drafted, there was widespread media and public concern after a number 
of offenders on the sex offenders register were approved to work within schools. ${ }^{12}$ It became clear that gaps in the current framework remained, chiefly because many of Bichard's recommendations had yet to be implemented. ${ }^{13}$ These cases prompted a further review of current systems for the vetting of teachers and other individuals who work with children, including the sex offenders register and List 99, as a follow-up to the recommendations of the Bichard inquiry (Gillespie, 2007). In response to these concerns, the then Education Secretary Ruth Kelly overturned previous advice by affirming that teachers must apply for a fresh background check each time they took up a new post within their local education authority. ${ }^{14}$

In February 2008, the Home Secretary announced the piloting of a new disclosure scheme to allow parents, and single mothers in particular, to check whether people who have unsupervised contact with their children have convictions for sexual offending. ${ }^{15}$ This could include, for example, the screening of new partners of the child's parents or friends or neighbours looking after children. This policy proposal was in direct response to the media and public campaign for a 'Sarah's Law', following the kidnapping and murder of eight-year-old Sarah Payne by known paedophile Roy Whiting in July 2000 (Ashenden, 2002; Silverman and Wilson, 2002: 146-66).16 A limited form of disclosure already exists under the Multi-Agency Public Protection arrangements, where there is an immediate danger to the public (Kemshall and Maguire, 2003). ${ }^{17}$ Until this point, however, the government had firmly rejected calls for community notification along the lines of 'Megan's Law' in the United States, which permits a much wider degree of public disclosure of information about local sex offenders (Rutherford, 2000; Thomas, 2003). Now it seems that, despite official reassurances to the contrary, we have moved one step closer to a general right of access to such information. Following the outcome of the four pilot schemes, new legislation is possible representing a complete u-turn in government policy from the previous reluctance to legislate in this area (Thomas, 2001). This announcement further conveys the trend towards populist decision-making. Moreover, as will be argued further below, widespread community notification of the identity of known sex offenders blurs the distinction between the uses of information for public or private purposes and also has wider ramifications for the effective management of risk.

This reactionary form of policy making, symptomatic of law making in other overtly politicized and contentious arenas such as the anti-terrorism legislation (Zedner, 2005), is problematic on several fronts. It not only creates fear about the perceived omnipresence of sex offenders in society but it also succeeds in conflating levels and types of risk in the public imagination. That is, sex offending against children tends to be equated with sex offending in general and all sex offenders are deemed to pose the same degree of very high risk. Moreover, this populist punitive approach of New Labour to 'law and order' is circuitous and ultimately sustains a vicious policy cycle (McAlinden, 2007: 27)..$^{18}$ That is to say, a broadly punitive socio-political rhetoric simultaneously fuels public fear of sexual offenders and provides a rationale and 
increased demand for regulatory measures meant to allay these fears. As Furedi and Bristow put it 'vetting begets vetting' (2008: 5). This in turn, however, has ultimately promulgated a broader problem in terms of a 'punishment deficit' (Brownlee, 1998). Vetting in particular creates a false sense of security that it is possible through the imposition of these regulatory measures to prevent an individual from ever harming children in their care (Furedi and Bristow, 2008: 6-7).

The reality is, however, that all such measures are severely limited in their ability to effectively manage the risk posed by sex offenders. It is axiomatic that regulatory legal frameworks, which are heavily premised on the effective use of information, can only ever hope to deal effectively with 'known' risks, that is, those sex offenders who have already come to the attention of law enforcement agencies in some way. In practice, this actually covers very few offenders since it is well established that the majority of abuse, and therefore prospective risks to children, remain hidden and undisclosed. ${ }^{19}$

\section{PARt IV: The Unintended ANd Ambiguous Policy CONSEQUENCES OF STATE OVER-EXTENSION}

The recent expansion of the regulatory framework on vetting with respect to the screening of all those who would work with children or the vulnerable in order to pre-emptively address probable risks creates insecurities and ambiguities of sizeable proportions. These may be related to the negative and unintended policy consequences in terms of the potential public release of information about sex offenders and the ambiguous and uneven implementation of policies at a localized level.

\section{NEGATIVE AND UNINTENDED POLICY CONSEQUENCES: COMMUNITY NOTIFICATION}

Making the identities of known sex offenders public information, as these measures have the potential to do, may have a number of consequences for the wider management of the sex offender problem. The paradox here is that public information about sex offenders in one sense makes society feel safer or better protected but, at the same time, may actually drive offenders underground and consequently make them more dangerous. The scope of the new regulatory framework on vetting may have a negative and detrimental impact on how sex offenders are perceived by the wider public and ultimately their reintegration. The public shaming of a person as a sex offender may perpetuate a cycle of stigmatization, ostracism and ultimately re-offending behaviour (Edwards and Hensley, 2001; McAlinden, 2005). The pilot schemes to allow parents to check the criminal records of those with unsupervised contact with their children, referred to above, are tantamount to community notification and may compound these problems. In essence, a system designed for the 
needs of employers is being adapted for private relationships without any real thought about structural constraints or quality control. This ultimately blurs the distinction between the public and private sphere.

The development of the regulatory state has entailed a move away from old modes of governance based on hierarchal and bureaucratic control towards new styles comprised of decentred regulation involving both state and nonstate actors co-operating through shared networks and alliances (Crawford, 2006: 450). This notion of 'networked' or 'nodal' governance (Shearing and Wood, 2003) has meant that civil society often works in partnership with the state in the local governance of crime (Crawford, 1997, 2003; McEvoy and Eriksson, 2008). A recent example of this in the specific terrain of sexual offending is the development of 'reintegrative shaming' programmes with high-risk sex offenders, such as Circles of Support and Accountability, first developed in Canada and then piloted in England and Wales and elsewhere (McAlinden, 2005, 2007). Early evaluations of these projects in England and Wales have shown that such programmes have been effective in assisting in offender rehabilitation and that, despite tentative beginnings, communities were willing to play a constructive and supportive role in this process (Quaker Peace and Social Witness, 2005).

At one level, making the community part of the regulatory process and admitting the public as consumers of such knowledge about offenders may help to reduce risks and make communities safer. This 'opening up' of knowledge is particularly important in relation to 'grooming' where many sex offenders seek to infiltrate unsuspecting families or communities (McAlinden, 2006: 355). Legal interventions can do little to prevent this unless the offender has already come to their attention; communities can, however, by arranging networks of support and control where necessary (McAlinden, 2005: 388).

On another level, making individuals aware of the identity and whereabouts of a known or suspected sex offender in such a formal way may make matters worse (Berliner, 1996; Soothill and Francis, 1998). The aftermath of the News of the World's 'Name and Shame' Campaign, referred to above, demonstrated the potential for violence and vigilante activity surrounding public information about sex offenders (Ashenden, 2002; Williams and Thompson, 2004a, 2004b). As a result of the campaign, for example, one convicted paedophile disappeared, two suspected paedophiles committed suicide, and one woman's home was targeted simply because she had the same surname as a known sexual offender. The precautionary approach to criminal justice as evidenced through vetting can, therefore, generate 'fear and with it intolerance' (Ericson, 2007: 155), suspicion and exclusion of deviants from the local community.

\section{AMBIGUOUS AND UNEVEN POLICY IMPLEMENTATION}

National state policies on vetting may be modified when they are received at a localized level as they are 'refashioned' and 'resisted' through 'distinct insti- 
tutional cultures and traditions and divergent penal narratives' (Crawford, 2006: 451). This may result in uneven and incongruous implementation of penal policies and practices. This broad argument has resonance on at least three distinct yet related levels: how state policies may be implemented and received between various local agencies who work on a co-operative basis; how policies may operate within a given institution or organization; and finally how policies may work on a transnational level among national authorities.

First, as regards the inter-agency context, all work in relation to sex offenders in the United Kingdom currently takes places on a multi-agency basis with the core goal of public protection (Kemshall and Maguire, 2001). The problematic nature of 'partnership' approaches to crime problems in terms of the potentially competing organizational cultures and working practices are well documented (Crawford, 1997; Kemshall and Maguire, 2001). Central to an analysis of inter-agency co-operation are differing institutional and structural power relations which exist between agencies and are incorporated into multi-agency work (Crawford, 1997: 127-31; Pearson et al., 1992; Crawford and Jones, 1995). Power differentials may especially influence other symptomatic forms of inter-agency conflict, such as struggles over confidentiality and privileged access to information (Sampson et al., 1991: 132). As regards the vetting process, the most pertinent problems are likely to relate to information sharing and a shared understanding of which particular agency is responsible for what. In short, differences in approach to the problem of the risks posed by child sex offenders may result in fragmented working practices and in a breakdown of effective communication of important information about offenders.

Indeed, inadequate information recording and sharing lay at the heart of the Ian Huntley case. 'Systemic and corporate' failures in police handling of intelligence and in the vetting and barring systems were blamed for Huntley being cleared to work in Soham primary school (Bichard, 2004: 2, para. 8). As noted above, the 2006 Act, as the legislative basis for the implementation of the Bichard Report, attempts to unite previously disparate sources of criminal records information. However, since the success of vetting by its nature relies almost entirely on the effective use of accurate information, it is argued that some problems are likely to be endemic. Huntley's date of birth and a number of aliases were not properly recorded or checked on police files. This led to information being missed when the call for a background check came. In addition, as will be argued further below, difficulties also remain in relation to how 'soft' intelligence or 'suspect' offenders are to be treated for the purposes of the vetting system. Following the Soham murders it later emerged that Huntley was known to police forces for a series of previous allegations of sexual offending where no action was eventually taken. Police forces failed to pass on details about his offending past largely because relevant information had been deleted. Despite the new reforms, much will depend, therefore, on the actions of the police in keeping information and intelligence timely, accurate and up to date. 
On a second level, sociologists have for some time sought to develop an 'institutional epistemology' (Garland and Sparks, 2000: 201) which acknowledges the cognitive processes and the internal relational dynamics of institutions. ${ }^{20}$ Whatever the general mandate promulgated by the state, institutions in themselves are apt to develop and re-organize their own rationale as the basis for collective action which is shaped by a 'sameness' of shared thoughts, values and information (Douglas, 1986: 53). Moreover, the institutional enterprise is embedded with wider forms of social interaction which produce informal norms as well as more formal organizational rules and monitor compliance with them. These systems of rules may either constrain or encourage innovative individual action (Nee and Brinton, 2001: xvi).

This analysis of institutional cultures not only has a bearing on the process of institutional change, but also has implications for the effectiveness of legal frameworks on vetting. That is, the ultimate success of the new vetting measures as the gatekeepers of access to institutions by would-be abusers may also depend greatly on how rules and regulations are received and negotiated within institutions at an individualized localized level. It also helps to explain the slow progress of organizational change in failing to implement the same key recommendations from a series of inquiry reports and reviews which would improve policy, practices and procedures on vetting.

Thirdly, although the precautionary principle also has resonance in the context of policy formation at an EU level (Fisher, 2002), differences in penal cultures and political economies may mean that its effects are diluted to varying degrees in practice (Sparks, 2001). Moreover, the problems of policy implementation within inter-organizational contexts are likely to be compounded when it comes to multi-agency working across jurisdictional boundaries. In addition to the obvious difficulties concerning translating legal frameworks across cultural and language barriers, criminal records information may be very difficult and time consuming to obtain from some states who may be reluctant to release information (Magee, 2008). The EU White Paper proposal for the establishment of a European index of offenders was rejected (Council of Ministers, 2005). Enhancing police and judicial co-operation and enforcement in criminal matters, however, is an issue of ongoing concern (Ramage, 2007) with a move towards the creation of a European criminal record. This will eventually improve the availability and quality of information about offenders (Constantin, 2008; Jacobs and Blitsa, 2008).

In the interim, there are varying systems across the EU and disparity within and between countries in terms of standardized criminal record information and data storage systems, and arrangements to track sex offenders and prevent unsuitable people from working with children. Such concerns are becoming increasingly pertinent given the significant cross-border movement of individuals within the EU. ${ }^{21}$ Recent NSPCC research has highlighted the array of approaches to pre-employment vetting within individual countries which presents significant challenges to inter-country co-operation and exchange of relevant information about offenders (Fitch et al., 2007: 2). For example, while the UK has recently extended vetting to all posts involving 
access to children or the vulnerable, in Sweden health sector workers are not vetted, and in Poland most can work in children's homes without preemployment checks. ${ }^{22}$ These differences inevitably mean not only that vital information about perceived risk may be lost, but also that individuals will likely exploit differences between countries and seek employment in other jurisdictions where vetting and barring systems are not as stringent. ${ }^{23}$

\section{Part V: The Failure to Manage Risk}

As noted above, the new legislative framework goes beyond 'the merely suspicious' (Ericson, 2007: 1) to effectively criminalize all those who not only have direct contact with children or the vulnerable but also those with indirect contact in the form of information about them. As Ashworth has argued, 'seemingly objective criteria such as harm and offence tend to melt into the political ideologies of the time' (2003: 55). This 'penal imprint of the panopticon' (Ericson, 2007: 27) represents significant net-widening which goes well beyond those who would pose a danger to children and has huge resource implications for the management of risk.

Research has demonstrated the staggering costs and wider resource implications of the recent 'boom' in vetting (Appleton, 2006: 6-7). The government, it seems, gravely underestimated the potential demand for criminal records checks and the Criminal Records Bureau was under-resourced from its inception (Gillespie, 2006: 26). It has been estimated that the Safeguarding Vulnerable Groups Act will increase figures further and mean that as many as one-third of the adult working population in England and Wales, approximately 9.5 million adults, will be subject to ongoing criminal records checks. ${ }^{24}$ The disclosure process costs around $£ 83$ million annually (Peck and Keter, 2006: 40). It has been estimated that the new vetting and barring scheme will have additional set-up costs of $£ 16.6$ million and annual running costs of between $£ 12$ and $£ 15$ million (Peck and Keter, 2006: 40). There are simply too many people involved, therefore, for these measures to be realistic policing options. This will, as a result, divert valuable time, resources and focus from the real risks and problems. As Hebenton and Seddon (2009: 12) note, quoting Sunstein (2002), this is indicative of the 'risk-risk' problem of the precautionary approach where enhanced focus on managing or reducing one set of risks can create increased risks elsewhere.

The success of vetting as a preventative measure, in common with the sex offenders register, is based on the notion that simply having a list of known 'risky' individuals will make children or the vulnerable safe. These measures, however, are based on illusory fears and risks and not real tangible risk assessments. Apart from the limitations of record keeping and information systems, vetting only takes account of past actions based on a known record of offending and cannot predict how someone with no record will behave in the future (Furedi and Bristow, 2008: 7). It is well documented, however, that a high proportion of sexual offenders have never come to the attention of the police 
or other criminal justice agencies. ${ }^{25}$ Moreover, reconviction rates for sex offenders are generally low, as little as 10 per cent over a six-year follow-up period (Hood et al., 2002), in comparison with other classes of offender. ${ }^{26}$ As such, a regulatory vetting framework can only ever have a limited impact on managing the overall risk presented by sex offenders.

Precautionary approaches to vetting are heavily premised on the notion of the omnipresent dangerous sex offender who poses a very high level of risk. Public concern about the risks posed by sex offenders, however, often outweighs the actual levels of danger. In this respect, a recent body of work by Soothill and colleagues has identified three typologies of sex offender risk: 'known and high risk'; 'known, but low risk'; and 'unknown risk' (Kirby et al., 2005; Soothill et al., 2005). This categorization of offenders has important implications for quantifying 'unknown risks' and for evaluating the likely success of vetting measures. This research estimates that of sexual recidivists known to the police, under one-third will come from convicted offenders in the high-risk category. Approximately another third will come from convicted offenders in low-/medium-risk categories. It is the third category of offender, however, - 'unknown risk' - which presents most problems.

Kirby et al. (2005) have identified an important subset of this latter category which they term those 'strongly suspected of serious sex crime and future danger'. These are what Zedner, adopting the terminology of former US Secretary of Defense Donald Rumsfeld, calls 'known unknowns' (2009: 47) - those sex offenders 'we know we don't know about'. This would cover those individuals thought to be offenders by the police, such as Ian Huntley, who have not actually been apprehended or adjudicated upon. Kirby et al.'s (2005) 15-year follow-up study compared child sex offenders who were convicted with those who were suspected but not convicted in the Lancashire police force area over a three-year period in the late 1980s. The results show that suspected sex offenders provide a substantial source of future harm, and also accounted for one-third of repeat offenders coming to police attention. These offenders are normally outside the remit of traditional regulatory measures which are concentrated predominantly on monitoring convicted or cautioned sex offenders. This category of 'unknown' or 'suspected risk' can essentially only be probed, using traditional methods, by improving the mechanisms for securing convictions, such as increased intelligence, investigation and surveillance. As regards suspected offenders, however, as Kirby et al. readily acknowledge, 'There are considerable operational and ethical concerns to confront in dealing with such situations' (p. 226). Moreover, to proceed further in this vein with suspect offenders would increase the frequency and amount of pre-emptive regulatory activity by the state with further resource implications.

In addition, far more significant are the category of 'unknown unknowns' (Zedner, 2009: 47) - those sex offenders 'we don't know we don't know about'. This covers all those potential offenders who may never have come to notice. To compensate for a lack of knowledge about the potential risks posed by this group, the state dispenses with measures selectively and individually 
tailored to assess risk for particular individuals for undifferentiated strategies which 'treat all as potential suspects' (Zedner, 2009: 47). This blanket approach to risk, instilled in the recent expansive measures on vetting, merely perpetuates public fears and anxieties concerning the pervasiveness of sexual offending against children in particular. The resulting feelings of insecurity, suspicion and mistrust which attach to all who come into contact with our children undermines our ability to make discerning judgements about the likelihood of harm. This may ultimately help to further mask 'unknown risks' until they manifest themselves in the form of actual harm to children or the vulnerable.

\section{CONCLUSION}

One of the most pressing societal challenges is how to identify those who threaten children, on a proactive basis, prior to the occurrence of actual harm (Room, 2004b). It is a given that no system can eliminate risk entirely or protect children from the infrequent and unusual. In the face of this stark fact, we have witnessed what Ericson (2007: 669) calls the 'criminalisation of uncertainty' where in response to limited knowledge about actual risks or harms, the state responds with further legislation, surveillance and punishment of the offender. There is a danger, however, that this well established pattern of the enactment of new and increasing forms of state regulation, often as a direct response to high profile cases, has impeded a meaningful consideration of the broader policy and practical issues which underlie vetting and risk management processes. In this respect, the real lessons of public inquiries such as Soham have been framed in terms of bad management, lack of training and inadequate resources (Room, 2004a), particularly in relation to information sharing.

Aside from the obvious deficiencies of recent measures in practical terms, there are also broader implications which relate to the dangers inherent in law and policy-making in response to public clamours to tragic but unusual incidents. In short, particularly heinous crimes which occur infrequently become the focus of both popular and official discourses and are usually presented as a damning indictment of the system as a whole. Risk as the basis of precautionary crime control policy is often based on subjective populist value assumptions rather than objective scientific calculations. The potential implications for civil liberties, however, which underline recent pre-emptive approaches to the risk posed by sex offenders, are invariably justified by appeals to potential harm (Zedner, 2005, 2009).

There is a wider 'politics and culture of fear' (Furedi, 2006a, 2006b) in contemporary society which relates to potential risks to public safety posed by a range of threats, including terrorism, stranger danger and abuse, and the need to take ever more stringent precautionary measures against them. It is this politics of culture and fear surrounding sexual offending, created in large part by the media and sustained in turn by public and official responses, 
which fuels the regulatory regime. As Furedi (2006b) argues, however, the facts often fail to support the scare stories about new risks to our health and safety. The upshot is that the public and official obsession with theoretical or potential risks posed by sex offenders may actually distract society from the real risks or harms.

Vetting gives the 'allure of protection' (Hebenton and Seddon, 2009: 12) or the impression rather than the substance of security (Furedi and Bristow, 2008: 7). The Safeguarding Vulnerable Groups Act as the most recent manifestation of burgeoning state regulation of the pre-employment context has merely further cemented the systemic flaws and innate dangers of barring and vetting systems (Room, 2004a). In short, the crux of the problem is that the recent pre-emptive and insidious measures on vetting present significant challenges to precautionary, regulatory frameworks by seeking to govern the ungovernable - that is they are limited inexorably to known, identifiable and preventable risks and not the unknown, hidden and therefore the most dangerous ones.

\section{$\underline{\text { NOTES }}$}

I would like to thank Professors Kieran McEvoy and Phil Scraton for their insightful comments on earlier drafts of the article.

1. Part 2 of the Sexual Offences Act 2003 established a notification scheme and related orders, and section 15, the 'grooming offence'. This Act amended and replaced the previous law in relation to sex offender registration and related measures.

2. The inquiries have included the Ty Mawr Inquiry following allegations of misconduct in Gwent children's homes (Williams and McCreadie, 1992); and the Waterhouse Report (2000) of the inquiry into the abuse of children in care homes in North Wales. The reviews have included the Warner Report (1992) on the selection, development and management of staff in children's homes; and the Utting Report (1998) on the safeguards for children living away from home.

3. The Inquiry was set up following the trial and conviction of Ian Huntley for the murders of Holly Wells and Jessica Chapman in Soham in 2002. It examined child protection procedures in two police constabularies in England and Wales and in particular the effectiveness of information sharing systems and vetting practices.

4. Academic discourses have inclined towards a cynical view of the inquiry process arguing that official discourses may be socially and politically constructed (Rolston and Scraton, 2005).

5. Several studies and inquiries, for example, have established that staff either ignored signs of abuse or failed to act upon disclosures by children as an attempt to preserve the reputation of the institution or disguise the lack of proper procedures in place (Dawson, 1983; Waterhouse, 2000).

6. This offence has now been extended by the Sexual Offences Act 2003, ss. 16-24.

7. The Act applies in England and Wales and in part to Northern Ireland, with the remainder to be implemented by an Order in Council. A similar framework was introduced in Scotland under the Protecting Vulnerable Groups (Scotland) Act 2006. 
8. There are two types of disclosure: standard disclosure, which provides details of current and spent convictions, cautions, reprimands and warnings held on the Police National Computer (s. 113, Police Act 1997); and enhanced disclosure for those regularly involved in working with children or vulnerable adults, which also includes any relevant information held on local police files (s.115, Police Act 1997).

9. This scheme was heralded as a major step forward in crime prevention. See, e.g., 'Offender Database to Cut Crime', BBC News Online, 19 August 2005, at http://news.bbc.co.uk/1/hi/uk/4163764.stm

10. See also R. Kelly, Hansard, HC Debates, vol. 441, cols. 968-969, 19 January 2006.

11. See previous note.

12 'This Child Sex Offender Was Given Teaching Jobs in Three Schools', Daily Mail, 14 January 2006; '7 Perv Teachers ... 1 Dunce Minister', The Sun, 16 January 2006. In one of the first cases, a Norwich teacher, who had been cautioned for accessing indecent images of children on the internet (contrary to s. 1 of the Protection of Children Act 1978), was placed on the sex offenders register but not List 99 because a junior education minister had determined that the evidence against him was 'inconclusive'.

13 'Changes After Soham "Fall short"', BBC News Online, 15 March 2006, at http://news.bbc.co.uk/1/hi/uk/4349135.stm. Indeed, it has since emerged that several of these recommendations remain unimplemented as of July 2008 (Magee, 2008).

14. See note 10 above.

15. 'It's Victory for Sara: Government to Pilot Sarah's Law', News of the World, 17 February 2008; 'Parents Get New Sex Crime Checks', BBC Newes Online, 17 February 2008, at http://news.bbc.co.uk/1/hi/uk/7249043.stm

16. The campaign was led by Sarah's mother, Sara Payne, and backed by the Neres of the World newspaper's 'Name and Shame' campaign which called for the authorities to publicly identify all known sex offenders.

17. In $R \mathrm{v}$ Chief Constable of North Wales Police, ex parte Thorpe [1999] QB 396, the Court of Appeal affirmed that although there should never be a policy of blanket disclosure, the police had a right to notify immediate neighbours that two individuals had moved into a caravan park with a criminal record of child abuse since there was a specific risk of re-offending.

18. It has also been argued, however, that there has been an exaggerated focus on punitiveness in recent times, since the use of punitive sanctions has historically been an endemic feature of the criminal justice system (see Matthews, 2005).

19. Research shows, for example, that fewer than 5 per cent of sex offenders are ever apprehended (Salter, 2003) and that only 12 per cent of rapes involving children (Smith et al., 2000) are ever reported to the police.

20. Emile Durkheim (1958) first conceptualized the 'science of institutions' and the notion of institutions as individuals.

21. Figures from May 2004, for example, show that 17,013 nationals came to the UK from the 10 new EU member states and applied to the Home Office Worker Registration Scheme to work with children or vulnerable adults (see Fitch et al., 2007: 2). These figures do not include the self-employed or those who have failed to register.

22. Other examples include the fact that while criminal records are kept indefinitely in Northern Ireland, they are deleted in Germany when the person reaches age 24 and are 'wiped clean' in Sweden after 10 years if no subsequent offences are committed (Fitch et al., 2007). 
23. Similar concerns were also raised in the later stages of the parliamentary debates on the 2006 Act. See, e.g., Baroness Walmsley, Hansard, HL Debs, 1 November 2008, Cols. 370-1; Baroness Morris of Bolton, Hansard, HL Debs, 6 November 2008, Cols. 357-8.

24. Department for Children, Schools and Families, 'Vetting and Barring Scheme, Policy Briefing Pack', at http://www.everychildmatters.gov.uk/_files/2A9855 E1E34B0A4DC734E84D0A1156E9.pdf

25. See note 19 above.

26. This is subject to the caveat that reconviction rates may not always provide an accurate picture of sexual recidivism rates (Friendship et al., 2002), which may be as much as 5.3 times the official reconviction rate (Falshaw et al., 2003).

\section{CAse Cited}

$R \mathrm{v}$ Chief Constable of North Wales Police, ex parte Thorpe [1999] QB 396

\section{REFERENCES}

Agamben, G. (2005) State of Exception. Chicago: University of Chicago Press.

Appleton, J. (2006) The Case Against Vetting. The Manifesto Club, Briefing Paper at http://www.manifestoclub.com/files/THE\%20CASE\%20AGAINST\%20VE TTING.pdf

Ashenden, S. (2002) 'Policing Perversion: The Contemporary Governance of Paedophilia', Cultural Values 6(1): 197-222.

Ashworth, A. (2003) Principles of Criminal Law. Oxford: Oxford University Press. Bauman, Z. (1999) In Search of Politics. Stanford, CA: Stanford University Press.

Beck, U. (1992) Risk Society: Towards a New Modernity. London: Sage.

Berliner, L. (1996) 'Community Notification of Sex Offenders: A New Tool or a False Promise?', Journal of Interpersonal Violence 11(2): 294-300.

Bichard, Sir M. (2004) The Bichard Inquiry Report. London: Home Office.

Black, J. (2001) 'Decentring Regulation: The Role of Regulation and Self-Regulation in a "Post-Regulatory" World', Current Legal Problems, 54: 103-46.

Bottoms, A. E. (1995) 'The Philosophy and Politics of Punishment and Sentencing', pp. 17-49 in C. Clarkson and R. Morgan (eds) The Politics of Sentencing Reform. Oxford: Oxford University Press.

Braithwaite, J. (2000) 'The New Regulatory State and the Transformation of Criminology', British Journal of Criminology 40(2): 222-38.

Brownlee, I. (1998) 'New Labour - New Penology? Punitive Rhetoric and the Limits of Managerialism in Criminal Justice Policy', Journal of Law and Society 25(3): 313-35.

Castel, R. (1991) 'From Dangerousness to Risk', pp. 281-98 in G. Burchell, C. Gordon and P. Miller (eds) The Foucault Effect: Studies in Govermentality. Chicago: University of Chicago Press.

Cohen, S. (1972) Folk Devils and Moral Panics. London: Paladin.

Cohen, S. (2001) States of Denial: Knowing about Atrocities and Suffering. Cambridge: Polity Press.

Constantin, S. (2008) Towards a European Criminal Record. Cambridge: Cambridge University Press.

Corby, B., A. Doig and V. Roberts (2001) Public Inquiries into Abuse of Children in Residential Care. London: Jessica Kingsley. 
Council of Ministers (2005) Exchanges of Information on Convictions and the Effect of Such Convictions in the European Union. European Commission COM (2005)10.

Crawford, A. (1997) The Local Governance of Crime: Appeals to Community and Partnership. Oxford: Clarendon Press.

Crawford, A. (2001) 'Joined-Up but Fragmented: Contradiction, Ambiguity and Ambivalence at the Heart of New Labour's “The Third Way"', pp. 54-80 in R. Matthews and J. Pitts (eds) Crime, Disorder and Community Safety: A New Agenda. London: Routledge.

Crawford, A. (2003) 'Contractual Governance of Deviant Behaviour', Journal of Law and Society 30(4): 479-505.

Crawford, A. (2006) 'Networked Governance and the Post-Regulatory State? Steering, Rowing and Anchoring the Provision of Policing and Security', Theoretical Criminology 10(4): 449-79.

Crawford, A. and M. Jones (1995) 'Inter-agency Co-operation and Community-Based Crime Prevention: Some Reflections on the Work of Pearson and Colleagues', British Journal of Criminology 35(1): 17-33.

Dawson, R. (1983) The Abuse of Children in Foster Care: Summary Report. Ontario: Ontario Family and Children's Services of Oxford County.

Department of Education and Employment (1995) Misconduct of Teachers and Workers with Children and Young Persons, Circular 11/95. London: HMSO.

Douglas, M. (1986) How Institutions Think. New York: Syracuse University Press.

Durkheim, E. (1958) The Rules of Sociological Method, 2nd edn [1895]. Paris: Alcan.

Edwards, W. and C. Hensley (2001) 'Contextualising Sex Offender Management Legislation and Policy: Evaluating the Problem of Latent Consequences in Community Notification Laws', International Journal of Offender Therapy and Comparative Criminology 45(1): 83-101.

Ericson, R. (2007) Crime in an Insecure World. Cambridge: Polity Press.

Ericson, R. V. and K. D. Haggerty (1997) Policing the Risk Society. Oxford: Clarendon Press.

Falshaw, L., C. Friendship and A. Bates (2003) Sexual Offenders - Measuring Reconviction, Reoffending and Recidivism, Home Office Research Findings No. 183. London: Home Office.

Feeley, M. and J. Simon (1994) 'Actuarial Justice: The Emerging New Criminal Law', in D. Nelken (ed.) The Futures of Criminology. London: Sage.

Fisher, E. (2002) 'Precaution, Precaution Everywhere: Developing a "Common Understanding” of the Precautionary Principle in the European Community', Maastricht Journal of European and Comparative Law 9(1): 7-28.

Fitch, K., K. Spencer and Z. Hilton (2007) Protecting Children from Sexual Abuse: Safer Recruitment of Workers in a Border-free Europe. London: NSPCC.

Friendship, C., A. R. Beech, K. D. Browne (2002) 'Reconviction as an Outcome Measure in Research: A Methodological Note', British Journal of Criminology 42(2): 442-4.

Furedi, F. (2006a) Politics of Fear: Beyond Left and Right, 2nd edn. London: Continuum International Publishing Group Limited.

Furedi, F. (2006b) Culture of Fear Revisited, 2nd Rev. edn. London: Continuum International Publishing Group Limited.

Furedi, F. and J. Bristow (2008) Licensed to Hug: How Child Protection Policies are Poisoning the Relationship between the Generations. London: Civitas.

Garland, D. (1996) 'The Limits of the Sovereign State: Strategies of Crime Control in Contemporary Society', British Journal of Criminology 36(1): 445-71.

Garland, D. (1999) 'The Commonplace and the Catastrophic: Interpretations of Crime in Late Modernity', Theoretical Criminology 3(3): 353-64. 
Garland, D. and R. Sparks (2000) 'Criminology Social Theory and the Challenge of Our Times', British Journal of Criminology 40(2): 189-204.

Gillespie, A. (2006) 'Caution Ahead: Teachers, Vetting and the Law', Education and the Law 18(1): 19-30.

Gillespie, A. (2007) 'Barring Teachers: The New Vetting Arrangements', Education and the Law 19(1): 1-18.

Hebenton, B. and T. Seddon (2009) 'From Dangerousness to Precaution: Managing Sexual and Violent Offenders in an Insecure and Uncertain Age', British Journal of Criminology 49(3): 343-62.

Hood, R., S. Shute, M. Feilzer and A. Wilcox (2002) 'Sex Offenders Emerging from Long-Term Imprisonment: A Study of their Long-term Reconviction Rates and of Parole Board Members' Judgements of their Risk', British Journal of Criminology 42(2): 371-94.

Ignatieff, M. (2004) The Lesser Evil: Political Ethics in an Age of Terror. Edinburgh: Edinburgh University Press.

Jacobs, J. B. and D. Blitsa (2008) 'Major “Minor” Progress Under the Third Pillar: EU Institutions Building in the Sharing of Criminal Record Information', Chicago-Kent Journal of International and Comparative Law 8: 111-65.

Johnstone, G. (2000) 'Penal Policy Making: Elitist, Populist or Participatory?', Punishment and Society 2(2): 161-80.

Kemshall, H. and M. Maguire (2001) 'Public Protection, Partnership and Risk Penalty: The Multi-agency Risk Management of Sexual and Violent Offenders', Punishment and Society 3(2): 237-64.

Kemshall, H. and M. Maguire (2003) 'Sex Offenders, Risk Penality and the Problem of Disclosure', pp. 102-24 in A. Matravers (ed.) Sex Offenders in the Community: Managing and Reducing the Risks. Cullompton: Willan.

Kirby, S., B. Francis, J. Harman and K. Soothill (2005) 'Identifying Future Repeat Danger from Sexual Offenders Against Children: A Focus on those Convicted and those Strongly Suspected of Such Crime', Journal of Forensic Psychiatry E Psychology 16(2): 225-47.

Lacey, N. (2004) 'Criminalisation as Regulation', pp. 144-67 in C. Parker, C. Scott, N. Lacey and J. Braithwaite (eds) Regulating Law. Oxford: Oxford University Press.

Loader, I. and N. Walker (2007) Civilizing Security. Cambridge: Cambridge University Press.

Magee, Sir I. (2008) Review of Criminality Information. London: Home Office.

Majone, G. (1994) 'The Rise of the Regulatory State in Western Europe', West European Politics 17: 77-101.

Matthews, R. (2005) 'The Myth of Punitiveness', Theoretical Criminology 9(2): 175-201.

McAlinden, A. (2005) 'The Use of "Shame" with Sexual Offenders', British Journal of Criminology 45(3): 373-94.

McAlinden, A. (2006) “"Setting 'Em Up”: Personal, Familial and Institutional Grooming in the Sexual Abuse of Children', Social E Legal Studies 15(3): 339-62.

McAlinden, A. (2007) The Shaming of Sexual Offenders: Risk, Retribution and Reintegration. Oxford: Hart Publishing.

McEvoy, K. and A. Eriksson (2008) 'Who Owns Justice? Community, State and the Northern Ireland Transition', pp. 157-89 in J. Shapland (ed.) Justice, Community and Civil Society: A Contested Terrain. Cullompton: Willan Publishing.

Moran, M. (2001) 'The Rise of the Regulatory State in Britain', Parliamentary Affairs 54(1): 19-34.

Moran, M. (2003) The British Regulatory State: High Modernism and Hyper Innovation. Oxford: Oxford University Press. 
Nee, V. and M.C. Brinton (2001) The New Institutionalism in Sociology. New York: Russell Sage Foundation.

O'Malley, P. (1999) 'Volatile Punishments: Contemporary Penality and the NeoLiberal Government', Theoretical Criminology 3(2): 175-96.

O'Malley, P. (2004) Risk, Uncertainty and Government. London: The Glasshouse Press.

Parton, N. (2004) 'From Maria Colwell to Victoria Climbié: Reflections on Public Inquiries into Child Abuse a Generation Apart', Child Abuse Review 13(2): 80-94.

Parton, N., D. Thorpe and C. Wattam (1997) Child Protection: Risk and the Moral Order. Hampshire: Macmillan.

Pearson, G., H. Blagg, D. Smith, A. Sampson and P. Stubbs (1992) 'Crime, Community and Conflict: The Multi-Agency Approach’, pp. 46-72 in D. Downes (ed.) Unravelling Criminal Justice. London: Macmillan.

Peck, M. and V. Keter (2006) The Safeguarding Vulnerable Groups Bill [HL] Bill No 194 of 2005-06. House of Commons Research Paper 06/35.

Quaker Peace and Social Witness (2005) Circles of Support and Accountability in the Thames Valley: The First Three Years - April 2002 to March 2005. London: Quaker Communications.

Ramage, S. (2007) 'Data Protection and Criminal Justice: Some Recent Developments in EU and Domestic Law', Criminal Lawyer 169: 7-8.

Reichman, N. (1986) 'Managing Crime Risks: Towards an Insurance Based Model of Social Control', Research in Law and Social Control 8: 151-72.

Rolston, B. and P. Scraton (2005) 'In the Full Glare of English Politics: Ireland, Inquiries and the British State', British Journal of Criminology 45(4): 547-64.

Room, S. (2004a) 'Meeting the Challenges of Climbié and Soham: Part 1', New Law Journal 154: 490, 510.

Room, S. (2004b) 'Meeting the Challenges of Climbié and Soham: Part 3', New Law Journal 154: 590-1.

Rutherford, A. (2000) 'Holding the Line on Sex Offender Notification', New Law Journal 150: 1359.

Salter, A. (2003) Predators, Pedophiles, Rapists, and Other Sex Offenders: Who They Are, How They Operate, and How We Can Protect Ourselves and Our Children. New York: Basic Books.

Sampson, A., D. Smith, G. Pearson, H. Blagg and P. Stubbs (1991) 'Gender Issues in Inter-agency Relations: Police, Probation and Social Services', pp. 114-32 in P. Abbott and C. Wallace (eds) Gender, Power and Sexuality. Basingstoke: Macmillan.

Scott, C. (2004) 'Regulation in the Age of Governance: The Rise of the PostRegulatory State', pp. 145-77 in J. Jorduna and D. Levi-Faur (eds) The Politics of Regulation in the Age of Governance. Cheltenham: Edward Elgar.

Scraton, P. (2004) 'Streets of Terror: Marginalization, Criminalization, and Authoritarian Renewal', Social Justice 31(1-2): 130-58.

Seddon, T. (2008) 'Dangerous Liaisons: Personality Disorder and the Politics of Risk', Punishment and Society 10(3): 301-17.

Shearing, C. (2000) 'Punishment and the Changing Face of Governance', Punishment and Society 3(2): 203-20.

Shearing, C. and J. Wood (2003) 'Nodal Governance, Democracy, and the New "Denizens", Journal of Law and Society 30(3): 400-19.

Silverman, J. and D. Wilson (2002) Innocence Betrayed: Paedophilia, the Media and Society. Cambridge: Polity Press.

Simon, J. (1998) 'Managing the Monstrous: Sex Offenders and the New Penology', Psychology, Public Policy and Law, 4(1-2): 452-67. 
Smith, D. W., E. J. Letourneau, B. E. Saunders, D. G. Kilpatrick, H. Resnick and C. L. Best (2000) 'Delay in Disclosure of Childhood Rape: Results from a National Survey', Child Abuse and Neglect 24(2): 273-87.

Soothill, K. and B. Francis (1998) 'Poisoned Chalice or Just Deserts? (The Sex Offenders Act 1997)', Journal of Forensic Psychiatry 9(2): 281-93.

Soothill, K., J. Harman, B. Francis and S. Kirby (2005) 'What Is the Future Repeat Danger from Sexual Offenders against Children? Implications for Policing', The Police Journal 78(1): 37-45.

Sparks, R. (2001) 'Degrees of Estrangement: The Cultural Theory of Risk and Comparative Penology', Theoretical Criminology 5(2): 159-76.

Sullivan, J. and A. Beech (2002) 'Professional Perpetrators', Child Abuse Review 11(3): 153-67.

Sunstein, C. (2002) Risk and Reason: Safety, Law and the Environment. Cambridge: Cambridge University Press.

Thomas, T. (2001) 'Sex Offenders, the Home Office and the Sunday Papers', Journal of Social Welfare and Family Law 23(1): 103-8.

Thomas, T. (2003) 'Sex Offender Community Notification: Experiences from America', Howard Journal of Criminal Justice 42(3): 217-28.

Tonry, M. (2003) Confronting Crime: Crime Control Policy Under New Labour. Cullompton: Willan Publishing.

Utting, W. (1998) People Like Us: The Report of the Review of the Safeguards for Children Living Away from Home. London: HMSO.

Warner, N. (1992) Choosing with Care. London: HMSO.

Waterhouse, R. (2000) Lost in Care. London: HMSO.

Westcott, H. (1991) Institutional Abuse of Children - From Research to Policy: A Review. London: NSPCC.

Williams, A. and B. Thompson (2004a) 'Vigilance or Vigilantes: The Paulsgrove Riots and Policing Paedophiles in the Community: Part 1: The Long Slow Fuse', Police Journal 77(2): 99-119.

Williams, A. and B. Thompson (2004b) 'Vigilance or Vigilantes: The Paulsgrove Riots and Policing Paedophiles in the Community: Part 2: The Lessons of Paulsgrove', Police Journal 77(3): 193-205.

Williams, G. and J. McCreadie (1992) Ty Mawr Community Home Inquiry. Ebbw Vale: Gwent County Council.

Zedner, L. (2005) 'Securing Liberty in the Face of Terror: Reflections from Criminal Justice', Journal of Law and Society 32(4): 507-33.

Zedner, L. (2009) 'Fixing the Future? The Pre-emptive Turn in Criminal Justice', pp. 35-58 in B. McSherry, A. Norrie and S. Bronitt (eds) Regulating Deviance: The Redirection of Criminalisation and the Futures of Criminal Law. Oxford: Hart Publishing. 